\title{
VOCATIONAL CAREER CENTER AS THE BRIDGE BETWEEN INDUSTRY AND VOCATIONAL HIGH SCHOOL GRADUATES
}

\author{
Luthfi Indana ${ }^{1}$ and Soenarto ${ }^{2}$ \\ ${ }^{1}$ Universitas Wisnuwardhana, Malang, Indonesia \\ ${ }^{12}$ Department of Technology and Vocational Education, Universitas Negeri Yogyakarta, Indonesia \\ E-mail: indana.luthfi@yahoo.co.id; soenarto@uny.ac.id
}

\begin{abstract}
Preliminary study in Trenggalek city showed that there was a mismatch between the students' skills learned at vocational high schools with their fields of work. It indicated that the role of vocational career center as a mediator between school and industry have not maximally yet. This study aimed to (1) describe how the vocational career center do its jobdesk, (2) categorize its performance, and (3) find the deficiency from the implementation of a career center in vocational high schools. The data analysis used a descriptive analysis from both quantitative and qualitative approaches. The result of study showed that the jobdesk of career center were collecting graduates databases, grouping the students who want to look for a job or study to higher education, and facilitating the students and world of work in the labour recruitment process. The performance of career center in Trenggalek Regency was good. From some predictors, those were job vacancy information, cooperation with world of work, alumni networking, data collection, communication between alumni, and alumni contribution, the career center's aspect that need to be upgraded was the cooperation with the world of work.
\end{abstract}

Keywords: graduates, vocational career center, world of work

\section{INTRODUCTION}

Vocational high schools focus on the development of knowledge and skills in the world of work and increasing work productivity, sustainable life, self development, and sosial economy development [1]. Vocational education was designed to develop skills, ability, comprehension, attitude, work habit, dan appreciation needed by workers to enter the work and to make some progresses on their job usefully and productively. Kuswana [2] also explain that vocational education has special basic values. It is about the relationship between gaining knowledge, skills and attitude with creating values, especially related withs skill needed in the world of work.

Vocational secondary education in Indonesia consists of two institutions, that are vocational high schools and vocational islamic high schools under the coordination of the Directorate of Vocational High School Education.

One of vocational education characteristics is preparing the students to enter the world of work. The workforce preparation of vocationa students have to based on demands driven principal to adjust the need of world of Works thus the communication between schools and industry about the need of labour is important to established link and match between education and world of work.

Prosser [3] stated that vocational education must recognize conditions as they are and must train individuals to meet the demands of the market even though it may be true that more efficient ways for conducting the occupation may be known and better working conditions are highly desirable (industry needs). Therefore 
vocational education has to fulfill the need of labour market.

Vocational High Schools as education institutions not only give learning materials but also to meets student and world of work. The division which implements this duty is the headmaster vice of public relations. Public relations division has a unit which manages this matter, namely career center. Career center is one of tool to market vocational graduates. The position of career center as a mediator that bridge between graduates who are looking for a job with providers of works or world of work with labour formation in the medium degree [4].

The role of career center in vocational high schools is directing students to detemine and develop their career. The career development is a process to consider something that can or can not be managed and some parts of student's self experiences that relate with the job that suitable with their life. Moreover, career center have a role to communicate with the alumni. Alumni networking has to be strengthened because the work performance of alumni will be the reference for industry to assess the school. Alumni are the most effective part to give description about the school quality even the graduates quality [5].

The indicator of implementation fruitfulness of career center in vocational education institutes are (1) there are some job vacancy information service that helpful and facilitate job vacancy access suitabel with the relevance of competency, potency, and position analysis; (2) there is vocational graduates valid data which suitable with alumni qualification so facilitate the industries to access data for their labor candidate; (3) there is vocational graduates' work absorption data; (4) there is tracer study data; (5) the development of cooperation between schools and world of work reached; (6) the relationship between vocational alumni and school intertwined; (7) there is a learning synchronisation between school and world of work; (8) there is softskill learning to enter the world of work.

The research about career center had done by Pambayun \&Wagiran [6] about The performance of career center in state vocational high school technology and engineer expertise sector in Sleman regency. This study showed that the performance of career center in state vocational high schools were good from input, process, and output dimension but generally the performance categorize was low. This study used evaluation research with a discrepancy model. Data were analyzed by a descriptive analysis and a count discrepancy presentage. The data were collected using an inventory, observation sheet, a documentation sheet and interview guidlines. It is different with Pambayun \& Wagiran [6], this used a descriptive quantitative study with a research instrument using interview guidelines and questionnaire that given to the twelve grade students and alumni. This research will examine the how the career center do the performance in Trenggalek Regency.

Mcilveen et al. [7] found that career optimism fully intervened the relationship between academic major satisfaction and conscientiousness. Furthermore, the research showed that optimism had significant role in satisfaction with career generally and study especially. From that conclusion, teachers in Vocational High School (VHS) should give instruction to their students about the career planning and that duty belong to career center unit. Career center unit has to guide students into career optimism, so they can reach good career in their future. 
Another study was about proactive personality, career adptability, and thriving [8]. The finding of this study has important implication for career counseling practices in Vocational High School. The study found that proactive personality give individual first promotion on thriving at work, and it will turn led to improved career adaptability. The career center position to be important to build student career adaptability. This research describes about the implementation of career center in the vocational high school (VHS) and knowing the lack of career center.

The study about vocational and overall identity [9] showed that in both global and vocational terms, a number of university students need support to develop their identity in an adaptive way. Actually, although the overall identity achieved in adaptive way, the students could be vocational uncommitted. This study also support for counseling programs to help individual design and redesign their lives. Counseling program not only for university student but also important for vocational high school students. Career center in the vocational high school responsible to design and redesign the students career in the future. Career center give the student a direction to choose their job. In this study, the performance of career center will be discussed.

Lestari et al. [10] found that students decided their job based on some consideration, such as: the background of family's social economy, environment, interest, and the availability of job vacancy information in the career center. Based on that matter, beside give some information about job vacancy, career center try to give some suggestion to the students that the suitability between job and education background have to be considered to construct the career. This is one of the main task of career center in order to bridge graduates with the world of work and industry.

The research about vocational guidance [11] showed that the vocational guidance is worth to the program has contributed to finding satisfactory, efficient, and effective solutions in the socialization process and social integration through a more rewarding time using by the individual and more usefull for social relationships. This was tried in some way by modifying personal characteristics of young people (abilities, interests, personality) to industry demands, pondering that the job, tasks, functions, and occupation are in different degree (depending on the consulting approach). The vocational guidance train the student to become a good worker that industry needed.

Preliminary study showed that in Trenggalek, there were mismatching skill among vocational graduates. Many graduates worked in the unsuitable field. Their field of work did not relate with their study background in the Vocational High Schools.

This mismatching skills among vocational graduates arise some questions about the performance of vocational career center. Vocational career center have a big role to connect graduates with world of work. The performance of vocational career center will effect the suitability of grduates' field of work.

From that reason, this study conducted with the purposes of (1) to describe how the vocational career center doing its jobdesk; (2) to categorize its performance; (3) to find the lack of implementation of career center in vocational high schools. 


\section{METHOD}

The purpose of this study was to know the performance of career center on vocational high school while distribute alumni to the world of work in Trenggalek Regency. This study used descriptive method with qualitative and quantitative approach. Quantitative analysis was used to know the performance of career center from students perspective. Qualitative analysis was used to get information from the coordinator of career center in the schools. Career center coordinator will be given some questions about the implementation of career center. The flowchart of this study is presented in Figure 1.

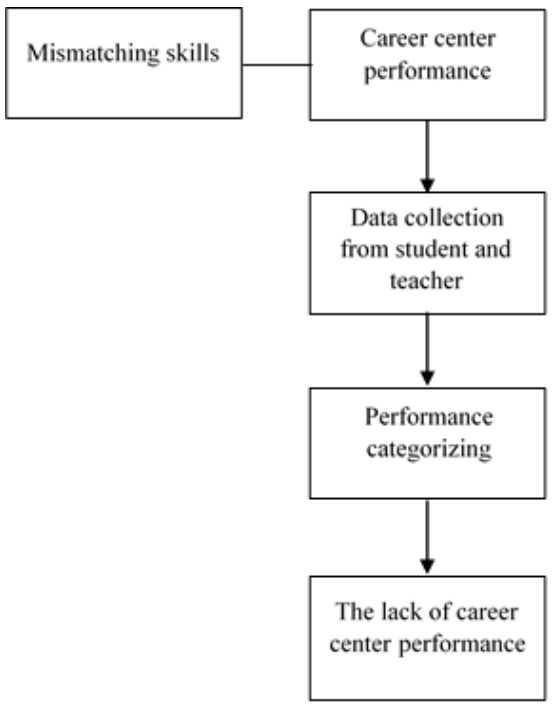

Figure 1. Flowchart of the Study

This study was conducted in five vocational high schools both public and private in Trenggalek Regency. The research object was computer and informatics engineering study program. This study program consists of three departments, those were computer and networking engineering (CNE), software engineering (SE), and multimedia (MM). So, this research focused on the performance of career center which is connecting alumni from computer and informatic engineering study program with world of work, especially in the informatic field.

The sampling technique used in this research were proportional random sampling and purposive sampling. Proportional random sampling used to determine the responden from students, while purposive sampling used to obtain the respondent from teachers. The following table will describe the research sample from students. The research sample that obtained from teachers or the coordinator of career center in the school can be seen in the Table 2 .

Table 1. Population and Sample from Students

\begin{tabular}{llcc}
\hline Department & \multicolumn{1}{c}{ School } & Population & $\begin{array}{c}\text { Sampl } \\
\mathrm{e}\end{array}$ \\
\hline $\begin{array}{l}\text { Software } \\
\text { Engineering }\end{array}$ & $\begin{array}{l}\text { VHS 2 } \\
\text { Trenggalek } \\
\text { VHS Wahid }\end{array}$ & 69 & 50 \\
& $\begin{array}{l}\text { Hasyim } \\
\text { Trenggalek }\end{array}$ & 6 & 3 \\
Computer & $\begin{array}{l}\text { VHS 1 } \\
\text { and }\end{array}$ & 70 & 36 \\
$\begin{array}{l}\text { Networking } \\
\text { Engineering } \\
\text { Multimedia }\end{array}$ & $\begin{array}{l}\text { Vuren 1 } \\
\text { Vuren 1 }\end{array}$ & 119 & 61 \\
& $\begin{array}{l}\text { Trenggalek } \\
\text { VHS Islam 1 }\end{array}$ & 70 & 36 \\
Amount & Durenan & 40 & 20 \\
\hline
\end{tabular}

Table 2. Sample from Teachers

\begin{tabular}{lcc}
\hline School name & Population & Sample \\
\hline State VHS 2 & 6 & 3 \\
Trenggalek & & \\
VHS Wahid Hasyim & 3 & 3 \\
$\begin{array}{l}\text { Trenggalek } \\
\text { State VHS 1 Pogalan } \\
\text { VHS Islam 1 }\end{array}$ & 4 & 3 \\
$\begin{array}{l}\text { Durenan } \\
\text { State VHS 1 }\end{array}$ & 20 & 8 \\
Trenggalek & 5 & 3 \\
Amount & 38 & 20 \\
\hline
\end{tabular}


The instrument used to collect data were a close questionnaire and an interview guideline. Interview guideline was given to the teachers who were the coordinator of career center as an informant about the performance of career center while facilitate the labor distribution from vocational high school (VHS) to the industry. The lattice of the instrument used in Table 3.

Table 3. Instrument Lattice

\begin{tabular}{|c|c|c|c|}
\hline Predictor & $\begin{array}{c}\text { Interview } \\
\text { items }\end{array}$ & $\begin{array}{c}\text { Questionnaire } \\
\text { items }\end{array}$ & $\begin{array}{c}\text { Research } \\
\text { sample }\end{array}$ \\
\hline $\begin{array}{l}\text { Job vacanvy } \\
\text { information } \\
\text { for alumni }\end{array}$ & $1,2,3,4$ & $1,2,3,4,5$ & \multirow{6}{*}{$\begin{array}{l}\text { Teacher, } \\
\text { alumni. }\end{array}$} \\
\hline $\begin{array}{l}\text { Cooperation } \\
\text { with world } \\
\text { of work }\end{array}$ & $5,6,7$ & 9,10 & \\
\hline $\begin{array}{l}\text { Alumni } \\
\text { networking }\end{array}$ & 8,9 & $14,15,16,17$ & \\
\hline $\begin{array}{l}\text { Data } \\
\text { collection of } \\
\text { alumni }\end{array}$ & $\begin{array}{c}10,11 \\
13\end{array}$ & $6,7,8$ & \\
\hline $\begin{array}{l}\text { Communica } \\
\text { tion between } \\
\text { alumni }\end{array}$ & 14,15 & $11,12,13$ & \\
\hline $\begin{array}{l}\text { Alumni } \\
\text { contribution }\end{array}$ & $\begin{array}{c}16,17 \\
18\end{array}$ & $18,19,20$ & \\
\hline
\end{tabular}

The instrument was tested for the validity. The validity analysis indicated that 20 of 22 instrument items were valid.The highest and the lowest $\mathrm{R}$ count were 0.814699 and 0.316848 respectively. Only 2 items were not valid with the $\mathrm{R}$ count of 0.166612 and 0.215169 .

Furthermore, the instrument was also assessed for its realibility. The instrument's reliability test used Alpha Cronbach formula. Criteria used as a minimum coefisien reliability was 0.70 [12]. This reliability test used SPSS Application version 16 . The realibility testing showed that the instrument was 0.892 classified as reliable based on the minimum coefisien reliability. The validity and reliability test only can be used in the questionnaire instrumen. This validity and reliability testing cannot be used in the interview guideline's instrument.

\section{RESULTS AND DISCUSSION}

Based on an interview and close questionnaire about the performance of career center, the coordinator of career center explained the process of the career center in the vocational high school in Trenggalek Regency. The process started from the preparation of career center.

In the preparation stage, career center had to collected database of students in the twelve grade. This data was gotten from vice headmaster student division. The database used as a tool to do grouping whether student who want to work and continue their study to the higher education or university.

To support its performance, career center cooperated with world of work. During the cooperation. The step to start the cooperation was teachers as a representation of the school visited to the industry to propose Momerandum of Understanding (MoU). Sometimes, industry also visited to the schools to begin a cooperation. MoU between career center and industry was a cooperation form in the labor recruitment from graduates. From all schools that conducted in this research, there was a school that did not have career center. This situation because that school was established since 4 years ago, so the career center still in the planning to open.

To suit competencies that world of work needed with the skill of alumni from the school was needed a curriculum synchronisation. This matter was a responsibiity of curriculum division. So, career center did not manage the curriculum synchronisation. The recruitment process did 
not use synchronisation, but career center just give job vacancy information to the students and alumni.

As a preparation to enter world of work, schools also gave a students soft skill coaching to prepare students to be a good labor. This coaching was a seminar with an informant from industry. There was also a school which conducted a soft skill coaching by military activities that trained by an army from Kodim (Komando Distrik Militer) in the Trenggalek Regency.

To bridge students or alumni with world of work, the steps that had been through by career center were collected the database from twelve grade class, then career center distributed career form. In that form, there were alternatives between work and continue the study to higher education. When data had been collected, next step was splitted the part between career center and counseling guidance division. Career center responsible to connect the students with the world of work, while the counseling guidance responsible to connect students with the university.

Career center gave job vacancy information not only to the students, but also to the alumni. The alumni from all generation could get the job vacancy information. Alumni who graduated no matter when were still served by career center when they asked for information about the job vacancy. In other hand, alumni also gave information about the job vacancy they had. The job vacancy information was one of the alumni contribution to their schools. Another alumni contribution was alumni pleased to be an instructor for the students in some activities, such as scout agenda and school organization. The other form of alumni contribution who continued their study to ther higher education was they gave a sosialisation about the university to the students who interested to continue their study.

Job vacancy information communicated through some information media, such as whatsapp group, facebook group, career center website and announcement board in front of career center room. The information distributed through social media faster than which distributed through announcement board.

The source of job vacancy information came from the career center group in the province, career center group in the regency, and from industry which cooperated with schools. Career center forum both in the province and regency made the distribution of job vacancy information to the students and alumni easier.

Labour recruitment was conducted by selection team from world of work and industry in the school. The labour recruitment in the schools allowed students or alumni from all of schools in the region to follow the selection process. Some industries which held the recruitment test in the schools were PT. PNM, Alfamart, Indomart, ISUZU, PT. PAMA, and any others.

In addition to connect students with the industry, career center also achieved data collection of graduates absorption in the world of work. To do the collection data, there is a tracer study form or book to recap the activity of graduates. The form or book is located in the administration room. This room often visited by graduates because of their administration task, such as took certificate and trancsript. Beside the form and book as a tool for collect data, the another technique that used was online media, such as whatsapp group, facebook group, and school website. Sometimes, teacher also asked the graduates about their 
activity through the whatsapp. That was a responsibility from the career center to recap the activity graduates data.

Through some techniques that have been used to collect the graduates data, there were some obstacles, such as students forgot to fill tracer study form when they went to schools. Only some students who filled the online form that have been shared to them. This condition caused by the limitation of data access. The other reason was the bustle of graduates activity so they often forgot to fill the tracer study online form.

Based on the questionnaire fulfillment by the students and alumni about the performance of vocational career center in Trenggalek Regency, the following graphic described the result of the questionnaire deployment.

Based on the graphic, respondents mostly collected the score of career center performance between 56 to 68 . The maximum score that can be reached was 80 and the smallest score that can be got was 20. The career center performance was in the good category. It indicates that most of respondents agree with the positive statement of career center performance. They agree that the career center have done its jobdesk well. The category table can be seen in Table 4.

Table 4. The Performance Category

\begin{tabular}{cccc}
\hline No & Range & Category & $\begin{array}{c}\text { Respondent } \\
\text { number }\end{array}$ \\
\hline 1 & 68 to 80 & Very good & 27 \\
2 & 56 to 68 & Good & 121 \\
3 & 44 to 56 & Medium & 27 \\
4 & 32 to 44 & Poor & 2 \\
5 & 20 to 32 & Very Poor & 0 \\
\hline
\end{tabular}

The result of data collection will be categorize to know the performance of career center. This effectivity categorization composed of ideal mean value and ideal standard deviation value. The categorize of questionnaire result showed that the performance of career center in the Trenggalek Regency was in the good condition. It mean that career center have done its jobdesk, those were graduates employment, cooperation with world of work, alumni networking, data collection, communication, and alumni contribution. The analyzingof predictor contribution from close questionnaire that grouped by the amount of score per topic can be showed in Figure 2.

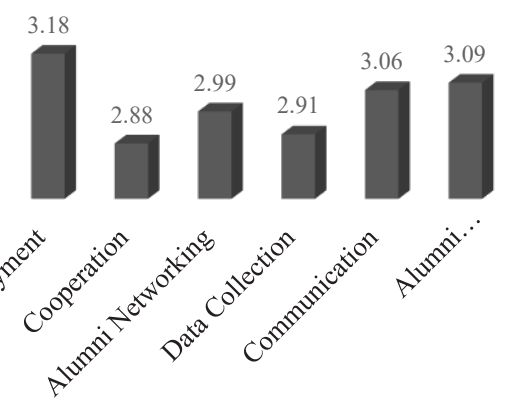

Figure 2. Graphic of Predictor Average

The graphic of career center performance in the schools showed that from some indicators those were compiled to be an instruments. The instrument consists of some sub indicators, those were graduates employment, cooperation with world of work, alumni networking, data collection, communication, and alumni contribution. From that graphic, we can concluded that from all sub indicators which arranged the research instrument, cooperation with world of work got the lowest score compared with the other sub indicators. This showed that the performance of vocational career center in Trenggalek Regency needed to improve the cooperation with world of work. The lack of cooperation with world of work caused by the number of industry in the informatics 
field just a little. It because Trenggalek Regency was a small region that sorrounded by nature, such as a hill, beach, and the large rice fields.

Actually, schools also built an connection with the informatics industry outside the regency but the number was not enough. The cooperation that built with the industry in the outside of region faced some obstacles, such as there was competition with another school, the cost was more expensive than the cooperation that built inside region.

Beside that, information that author got from interviewer showed that the role of career center to bridge between graduates and world of work was not maximally. It was proved by the presentation of graduates who worked and continued their study unsuitable was bigger than the graduates who worked and continued the study in the suitable field. Career center was not direct the graduates to the suitable field of work or study.

From some result of the study, career center have to improve the performance, especially to built the cooperation with the world of work. Furthermore, vocational career center have to direct students to choose their field of work or study suitable with their education background.

The result of this research equal with the study that have been conducted by Lestari et al. [10]. They mentioned that in order to execute its role, career center tried to enhance graduates absorbtion in the world of work through bridging the graduates with the world of work and schools gave a support to the career center through financing every activity of career center. The result of study also showed that the support of career center to the enhancement of labour absorbtion was the real effort. Career center tried to give information to the students about the job vacancy or we can say that the career center be a bridge between graduates and industry. However, the aspect that wasn't cared by career center about the suitability between education background and graduates' field of work. The performance of career center will be better when the suitability of job and education is cared because the purpose of vocational high school will actually achieve.

Vocational education need partnership between institution and world of work. The practice of industrial activity in the private company gave more benefits to the students than in the government institution. Students could obtain more comprehensive competencies and financial supports by the companies. The improvement of the learning could be attempted by the vocational high schools having not implemented industrial practices in the private surveying and mapping companies [13].

The proactive changers have three categories of reasons, there were a width to attain better working conditions, a search of personal growth, and a desire to have an occupation that fitted the person's vocation [14]. Certificate also influence the participants of vocational education and training (VET) in the Norway. VET in Norway has been integrated and standardized as part of upper-secondary education. The study that conducted by Tonder \& Aspoy [15] showed that opportunity to acquire formal VET qualificarions through workplace learning provides an important second chance for many young adults in Norway. The young adult have high motivation to get trade certificate. It signed that VET was a program that connected young adult with the world of work.

In Indonesia, the motivation of junior high school's students to go to vocational 
high school affected by economic social status of their parents, mass media, living environment of student and student's individual characteristics and the other factors. The most dominant factor which affected the motivation of junior high school's students to go to vocational high school was student's individual characteristics, then followed by mass media, social economic status of student's parents and student's living environment [16].

The important thing in the vocational education was trainers or teachers. In the Competency of National Dual Training System Industry Advisors research showed that advisors should had high knowledge, skills, and attitude. The gender had no influence on the skill and competence's advisors. National Dual Training System is a solution to provide qualified labor who capable to adapt the state and new technologies in Malaysia. It is can keep a good relation between the education system and the greater involvement in the education and skill training process. This is an effective program to create a skilled workforce in the transition period from school to the workplace [17].

The obstacles those were felt in the career center's implementation in Trenggalek Regency, such as most of student didn't fill the tracer study form, both online and offline, the limitedness of communication between alumni so the information didn't conveyed well. This obstacles equal with the result of the study that conducted by Lestari, Sutaryadi \& Subarno [10], that was the unstable personality of student, difficult to send information to the students and unsuitability between the world of work and student competencies. Based on those some obstacles, the solution that need to do is maximize the performance of career center through give a counseling about the career guidance and emphasize the importance of suitability between education background and competencies, enhance the cooperation between school and world of work or industry and adjust the job vacancy information that will be sent to the students. It must be suitable with the education background of students.

\section{CONCLUSION}

Based on the result, it can be concluded that the performance of vocational career center in Trenggalek Regency is good. Career center in Trenggalek Regency had implemented some of the main function, such as share the job vacancy information to the alumni or student, create tracer study data to recap the activity of alumni that have been graduated, and make a good cooperation in labour recruitment matter. From the job list that been done by career center in the Trenggalek Regency, the performance that have to be improved is the cooperation between the schools and world of work to recruit the graduates to be a labour.

\section{REFERENCES}

[1] R. Maclean, D. Wilson, and C. Chinien, International Handbook of Education for the Changing World of Work: Bridging Academic and Vocational Learnin. Bonn: Springer, 2009.

[2] W. S. Kuswana, Filsafat Pendidikan Vokasi, Teknologi dan Kejuruan. Bandung: Alfabeta, 2013.

[3] A. Prosser and Quigley, Vocational Education in A Democracy Revised Edition. Chicago USA: American Technical Society, 1959.

[4] Kejuruan Direktorat Pembinaan Sekolah Menengah, "Rencana 
Strategis Direktorat Pembinaan SMK 2015-2019," Jakarta, 2015.

[5] Deutsche Gesellschaft fur Internationale Zusammenarbeit, Pedoman Pelaksanaan Mengembangkan Kerja Sama yang Efektif antara Lembaga Diklat Kejuruan dan Industri. Deutsche Gesellschaft fur Internationale Zusammenarbeit, 2016.

[6] N. A. Y. Pambayun and W. Wagiran, "Bursa Kerja Khusus (BKK) SMK Negeri Bidang Keahlian Teknologi dan Rekayasa di Kabupaten Sleman," J. Pendidik. Vokasi, vol. 4, no. 2, Jun. 2014.

[7] P. Mcilveen, G. Beccaria, and L. J. Burton, "Beyond conscientiousness: Career optimism and satisfaction with academic major," J. Vocat. Behav., vol. 83, no. 3, pp. 229-236, 2013.

[8] Z. Jiang, "Proactive Personality and Career Adaptability: The Role of Thriving at Work," J. Vocat. Behav., vol. 98, pp. 85-97, Feb. 2017.

[9] L. A. Sestito, L. S. Sica, G. Ragozini, E. Porfeli, G. Weisblat, and T. Di Palma, "Vocational and Overall Identity: A Person-centered Approach in Italian University Students," J. Vocat. Behav., 2015.

[10] D. B. Lestari, Sutaryadi, and A. Subarno, "Analisis Peran Bursa Kerja Khusus (BKK) dalam Pengambilan Keputusan Karier Siswa SMK Negeri 1 Surakarta," $J$. Pendidik. Adm. Perkantoran, vol. 3, no. 1, pp. 1-12, 2014.
[11] F. M. M. Rodriguez, "Vocational Guidance Programme for Unemployed Young People," Psicol. Educ., vol. 19, no. 1, pp. 21-26, 2013.

[12] F. N. Kerlinger, Asas - asa Penelitian Behavioral. Yogyakarta: Gadjah Mada University Press, 2006.

[13] S. Rochmadi, "Industry Partnerships Learning Models for Surveying and Mapping of Vocational High Schools," J. Pendidik. Teknol. dan Kejuru., vol. 23, no. 2, pp. 210-225, Oct. 2016.

[14] J. Masdonati, G. Fournier, and I. Z. Lahrizi, "The Reasons Behind a Career Change through Vocational Education and Training," Int. J. Res. Vocat. Educ. Train., vol. 4, no. 3, pp. 249-269, Nov. 2017.

[15] A. H. Tønder and T. M. Aspøy, "When Work Comes First: Young Adults in Vocational Education and Training in Norway," Int. J. Res. Vocat. Educ. Train., vol. 4, no. 3, pp. 270-288, 2017.

[16] Kusworo and Soenarto, "Factors Affecting SMP/MTs Students' Motivation to Go into Vocational Schools in Sleman District," $J$. Pendidik. Teknol. dan Kejuru., vol. 23, no. 2, pp. 163-174, 2016.

[17] J. A. Baser, N. A. M. Jizat, F. A. N. Yunus, M. B. Rahim, A. R. A. Razzaq, and A. Hasan, "Competency of National Dual Training System Industry Advisors," J. Pendidik. Teknol. dan Kejuru., vol. 23, no. 4, pp. 328-338, Oct. 2017. 